\title{
Physiological and biochemical characterization of mango tree with paclobutrazol application via irrigation ${ }^{1}$
}

\author{
Moisés Alves de Souza ${ }^{2}$, Alessandro Carlos Mésquita ${ }^{3}$, \\ Welson Lima Simões ${ }^{2}$, Kalline Mendes Ferreira ${ }^{3}$, Emanoel Fernado Jurema Araujo ${ }^{2}$
}

\begin{abstract}
Paclobutrazol application in mango tree floral induction is followed by changes in the hormonal balance and carbohydrates production. This study aimed at evaluating the physiological and biochemical variables of mango tree (Palmer cultivar) by applying paclobutrazol doses via irrigation. The experimental design was randomized blocks, with five paclobutrazol doses $(0.7 \mathrm{~g}, 1.0 \mathrm{~g}, 1.3 \mathrm{~g}, 1.6 \mathrm{~g}$ and $1.9 \mathrm{~g}$ of a.i. per linear meter of canopy) and one additional treatment, with one dose in the conventional form of application (1.9 g of a.i. per linear meter of canopy), and four replicates. The variables analyzed were: photosynthesis rate; stomatal conductance; transpiration; leaf temperature; $\mathrm{CO}_{2}$ ratio; total protein content; reducing, nonreducing and total soluble sugars in leaf tissue and fruit; and nitrate reductase enzyme. The lowest values for photosynthesis rate and stomatal conductance were obtained with paclobutrazol applied via irrigation. The highest values for gas exchange were obtained with the lowest paclobutrazol doses applied via irrigation, showing that this kind of application is efficient and that it is possible to reduce the application dose via irrigation system. The highest carbohydrate contents in the leaf tissue were observed for the doses of $1.06 \mathrm{~g}$ and $1.09 \mathrm{~g}$ of a.i. per linear meter of canopy, applied via irrigation. The carbohydrate contents in fruits decreased in response to the paclobutrazol dose. The application methods and doses applied via irrigation did not influence the nitrate reductase activity.
\end{abstract}

KEYWORDS: Mangifera indica L.; reductase enzyme; floral induction.

\section{INTRODUCTION}

Mango is one of the most important fruits in Brazil, from a socio-economic standpoint, significantly contributing to the Brazilian exportation agenda of fresh fruits, thereby strengthening the trade balance (Reis et al. 2011). Brazil currently ranks the seventh position as the largest global producer

\section{RESUMO}

Caracterização fisiológica e bioquímica de mangueira com a aplicação de paclobutrazol via irrigação

A aplicação de paclobutrazol na indução floral de mangueira é acompanhada por alterações no balanço hormonal e na produção de carboidratos. Objetivou-se avaliar as variáveis fisiológicas e bioquímicas de mangueira cultivar Palmer, utilizando-se doses de paclobutrazol aplicadas via irrigação. O delineamento experimental foi em blocos casualizados, com cinco doses de paclobutrazol $(0,7 \mathrm{~g} ; 1,0 \mathrm{~g} ; 1,3 \mathrm{~g} ; 1,6 \mathrm{~g}$; e $1,9 \mathrm{~g}$ de i.a. por metro linear de copa) e um tratamento adicional, com uma dose na forma convencional de aplicação $(1,9 \mathrm{~g}$ dei.a. por metro linear de copa), e quatro repetições. As variáveis analisadas foram: taxa de fotossíntese; condutância estomática; transpiração; temperatura foliar; razão $\mathrm{CO}_{2}$; teor de proteínas totais; açúcares redutores, não redutores e solúveis totais no tecido foliar e no fruto; e enzima redutase do nitrato. Os menores valores para taxa de fotossíntese e condutância estomática foram obtidos com a aplicação de paclobutrazol via irrigação. Os valores mais elevados de troca gasosa foram obtidos com as doses mais baixas de aplicação de paclobutrazol via irrigação, o que demonstra que esta aplicação é eficaz e que é possível reduzir a dosagem de aplicação por meio do sistema de irrigação. Os maiores teores de carboidrato no tecido foliar foram observados nas doses de $1,06 \mathrm{~g}$ e 1,09 g dei.a. por metro linear de copa, aplicados via irrigação. Os teores de carboidrato no fruto diminuíram em resposta à dose de paclobutrazol. As formas de aplicação e dose aplicada via irrigação não influenciaram na atividade de redutase do nitrato.

PALAVRAS-CHAVE: Mangifera indica L.; enzima redutase; indução floral.

of mangoes, following India, China, Thailand, Indonesia, Pakistan and Mexico (FAO 2014).

In the Brazilian Northeast region, mango is cultivated practically in every State, preferably in irrigated areas of the semiarid region, which offers excellent conditions for this crop to grow, thus providing high yields and fruit quality (Almeida et al. 2015).

1. Manuscript received in Aug./2016 and accepted for publication in Dec./2016 (http://dx.doi.org/10.1590/1983-40632016v4642829).

2. Empresa Brasileira de Pesquisa Agropecuária (Embrapa Semiárido), Petrolina, PE, Brazil.

E-mails: moisesalves-1989@hotmail.com,welson.simoes@embrapa.br, manoelfernado_ja@hotmail.com.

3. Universidade do Estado da Bahia, Departamento de Tecnologia e Ciências Sociais, Juazeiro, BA, Brazil.

E-mails: alessandro.mesq@yahoo.com.br,kmf.agronomia@gmail.com. 
Cold weather and water stress are natural conditions that cause vegetative growth to stop in subtropical and tropical weather conditions, respectively. The occurrence of low temperatures in subtropical conditions defines the flowering and production periods of mango trees. According to Davies (2004), vegetable hormones produced in low concentrations might drive, inhibit or alter morphological and physiological processes, and are responsible for regulating the plant development and growth. This occurs due to the interaction among hormones, including gibberellins, auxins, cytokinins, abscisic acids and ethylene, as well as brassinosteroids, jasmonic acids, etc.

Gibberellins and auxins might work together or independently as inhibitors of signals correlated to floral induction in perennial fruit trees. However, only the regular application of gibberellins inhibits or delays flowering. Gibberellins are growth hormones and some of them are responsible for the elongation of plant cells (Salisbury \& Ross 1994). According to Castro Neto (1995), abscisic acid concentrations are higher in the floral initiation period than in the vegetative growth period, when abscisic acid competes with gibberellins for inhibition of the vegetative growth.

The use of plant growth regulators has made it possible to change hormonal balance in favor of flowering, and these chemical substances have been used to manipulate the vegetative growth in some species. The challenge, however, is to do it without reducing their productive capacity. Paclobutrazol has been used to manage mango tree flowering, causing vegetative growth to stop and reducing sprout elongation (Tongumpai 1999).

Different responses to paclobutrazol application are obtained in mango cultivation, because there are many cultivars grown commercially. Dosage and application methods also influence the plant response to paclobutrazol (Davenport 2007, Mouco et al. 2010), as some plants are capable of vegetating longer than others, and thus need higher doses. Sensitivity to paclobutrazol will also depend on climate and plant age and vigor (Alburquerque et al. 2002).

No information has been found in literature on the semiarid region, regarding the influence of paclobutrazol application via irrigation on gas exchanges of mango trees. However, it is known that the conventional application of the product reduces the photosynthetic activity in citrus ( $\mathrm{Vu} \&$ Yelenosky 1992); vines (Hunter \& Proctor 1994); apple trees, olive trees and strawberries (Singh 2001); and mangoes (Lima Filho et al. 2002).

Therefore, this study aimed at evaluating the effect of paclobutrazol doses applied via irrigation on the physiological and biochemical variables of mango tree.

\section{MATERIAL AND METHODS}

The experiment was conducted from September 2014 to May 2015, in a mango tree orchard (Palmer cultivar), in Petrolina (9'8'8.9' $\mathrm{S}, 40^{\circ} 18^{\prime} 33.6^{\prime \prime} \mathrm{W}$ and $373 \mathrm{~m}$ of altitude), Pernambuco State, Brazil. The climate in the region is classified as semiarid (BSwh), according to the Köppen's classification. Rains are concentrated in the period ranging from November to April, with mean annual rainfall around $500 \mathrm{~mm}$, distributed irregularly. The mean annual relative air humidity is $66 \%$ and mean annual air temperature is $26.5^{\circ} \mathrm{C}$. Figure 1 shows the weather data during the study.

Six-year-old mango trees were used, with $3 \mathrm{~m} \times 6 \mathrm{~m}$ spacing (556 plants $\mathrm{ha}^{-1}$ ) and mean canopy diameter of $2 \mathrm{~m}$. Irrigation was applied with two dripping lines per row, with $0.50 \mathrm{~m}$ spacing between drippers. The farming practices used, such as weeding, fertilizing and spraying chemicals, were either typically used in the property or proposed by Albuquerque \& Mouco (2000). The paclobutrazol source used to help the floral induction was Cultar, a Singenta commercial product with $25 \%$ of active ingredient.

The experimental design consisted of randomized blocks, with five paclobutrazol doses $(0.7 \mathrm{~g}, 1.0 \mathrm{~g}, 1.3 \mathrm{~g}, 1.6 \mathrm{~g}$ and $1.9 \mathrm{~g}$ of a.i. per linear meter of canopy) applied via irrigation, plus one additional treatment, with a dose in the conventional form of application (1.9 $\mathrm{g}$ of a.i. per linear meter of canopy), and four replicates. Plots consisted of four plants, with the two central ones being considered usable.

Pruning was performed throughout the orchard area, and paclobutrazol was applied via irrigation and conventional system, on October 30 (2014), right after plants were irrigated, so that water would favor all parts that were in contact with the product, including roots, thereby ensuring it would be absorbed by plants. After 65 and 70 days of the 


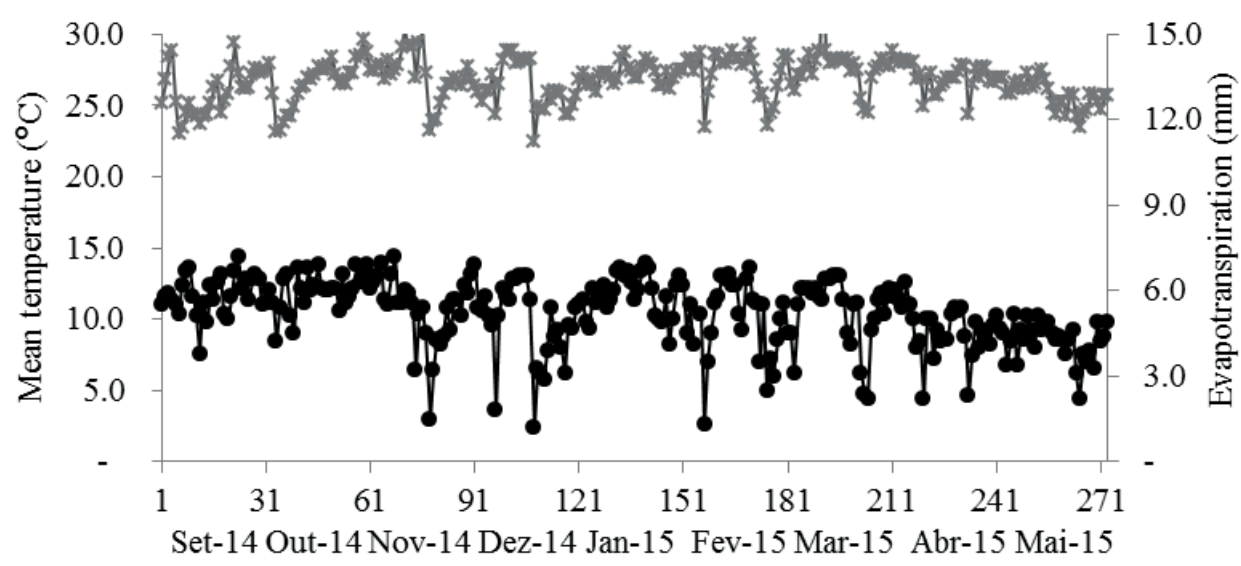

Days after treatment

Figure 1. Mean temperature and evapotranspiration recorded in Petrolina, Pernambuco State, Brazil, from August 2014 to May 2015.

paclobutrazol application, when the branches were ripe, foliar spraying with calcium nitrate and water blade reduction were performed.

Physiological and biochemical evaluations of leaf tissue were performed in two phenological stages of the mango productive cycle (flowering and ripening), using the experimental design of subdivided plots, with plots being comprised of paclobutrazol doses and subplots of sampling seasons. Gas exchanges were evaluated using the portable infrared gas analyzer model Li-6400, with artificial light fixed at $2,500 \mu \mathrm{mol} \mathrm{m} \mathrm{m}^{-2} \mathrm{~s}^{-1}$. The variables analyzed were: photosynthesis rate, stomatal conductance, transpiration, leaf temperature and $\mathrm{CO}_{2}$ ratio. The sampling of leaves exposed to sunlight was performed at four and eight months after the treatment application, between 9 a.m. and 10 a.m.

Right after the physiological evaluation, leaves were collected to analyze the biochemical characteristics of leaf tissue. Leaves were oven-dried at $60{ }^{\circ} \mathrm{C}$ (until they reached constant weight), crushed in grinding mills, soaked with a buffer solution and centrifuged to obtain the extract. This extract was used to determine the total soluble sugars, using the anthrone method (Yemm \& Willis 1954); reducing sugars, quantified using 3.5 dinitrosalicylic acid and the methodology described by Miller (1959); and total proteins, quantified using the methodology described by Bradford (1976). Non-reducing sugar contents were determined by the difference between the total soluble sugar and reducing sugar concentrations.

The phenological stages were not considered in the biochemical analysis of fruits. Harvest was performed on May 20 (2015) and 12 fruits were harvested per treatment. The fruit pulp was crushed to determine the total soluble and reducing sugars. The total soluble sugars content in the fruit was determined using the enthrone method and results were described according to Yemn \& Willis (1954). Reducing sugar contents in the fruit were determined by the dinitrosalicylic acid method and results were described according to Miller (1959). Non-reducing sugars were determined by the difference between the total soluble sugar and reducing sugar concentrations.

During the flowering phase, the in vivo assay of the nitrite reductase enzyme was conducted in the plants leaf tissue and root system, expressed as $\mathrm{NO}_{2}{ }^{-} \mathrm{g}^{-1}$ of fresh matter $\mathrm{h}^{-1}$. Harvest was performed at 8 a.m.

Data were submitted to analysis of variance. In order to compare both the paclobutrazol application methods, the mean value of $1.9 \mathrm{~g}$ of a.i. per linear meter of canopy via irrigation and a conventional form of application were submitted to the Tukey's test $(5 \%)$. Regression was used for the five doses applied via irrigation, when they were significant (5\%). Analyzes were performed using the Sisvar 3.01 software.

\section{RESULTS AND DISCUSSION}

Using the analysis of variance, it was observed that there was no interaction between paclobutrazol application methods and phenological phases (flowering and ripening) of all mango traits evaluated. Both paclobutrazol application methods are shown 
in Table 1, and the variables that had a significant effect were photosynthesis rate, stomatal conductance and leaf temperature. The conventional application caused an increase of $14 \%$ in the photosynthetic rate, $25 \%$ in stomatal conductance and, consequently, a $2 \%$ decrease in leaf temperature. Biochemical variables in leaf tissue and fruit did not have a significant effect on the application methods.

Lima Filho et al. (2002), evaluating the consequences of paclobutrazol application on gas exchange of mango trees, observed that the highest values for photosynthesis rate and stomatal conductance were obtained in plants which were not treated by the product, and that there was a significant decrease in those variables as doses increased. Based on the results found by the authors and on the decreased photosynthetic capability with the application via irrigation shown in Table 1, it is possible to state that the product assimilation was more effective in plants that received the product via irrigation. This might be associated to the fact that paclobutrazol applied via irrigation is better distributed in areas with a higher concentration of roots, where the root system is more active. The effect of paclobutrazol on the root system is attributed to the reduction in the water potential, due to the increase of the product concentrations, causing a significant increase in stomatal resistance and reduction in the transpiration rates and, consequently, in the photosynthetic activity.

Two phenological phases are shown on Table 2, and it is possible to see that the physiological and biochemical variables were generally less affected in the flowering phase. This might have occurred due to the relationship source/drainage in the fruiting phase, when fruits become the main drainage for the importation of carbohydrates, amino acids and other materials translocated by the phloem. Photosynthesis rate, total protein contents, total soluble sugars and estimate of sucrose content obtained an increase of $12 \%, 9 \%, 33 \%$ and $40 \%$, respectively, in the flowering phase. The higher photosynthetic rate in the flowering period might be associated to climate data, mainly the data related to higher solar radiation. In the fruit ripening phase, there was an increase of $23 \%$ in stomatal conductance, $2 \%$ in leaf temperature, $34 \%$ in the $\mathrm{CO}_{2}$ ratio and $30 \%$ in reducing sugars.

According to Tribuzy (2005), the increase in leaf temperature, during fruit ripening, might alter the structure of the enzymes involved in the carboxylation stage, as well as increase the fluidity of the chloroplast membranes, which directly affects the net carbon assimilation. Hence, both the biochemical process and $\mathrm{CO}_{2}$ fixation are damaged by increased leaf temperature. Oliveira et al. (2013), evaluating soluble sugar contents over the fruit development period, found the mean value of $37 \mathrm{mg} \mathrm{g}^{-1}$ of dry matter in leaves, a higher result than the one found in our study. Evaluating physiological traits, in terms of doses applied via irrigation, it is possible to see that the doses did not have a significant interaction with samplings. Generally, the increase in paclobutrazol doses caused a reduction in the gas exchange of mango trees (Figure 2).

Table 1. Paclobutrazol application methods on mango tree (Palmer cultivar).

\begin{tabular}{|c|c|c|c|c|c|}
\hline Application method & $\begin{array}{l}\text { Photosynthesis rate } \\
\mu \mathrm{mol} \mathrm{CO}_{2} \mathrm{~m}^{-2} \mathrm{~s}^{-1}\end{array}$ & $\frac{\text { Conductance }}{\mathrm{mol} \mathrm{m}^{-2} \mathrm{~s}^{-1}}$ & $\begin{array}{c}\text { Transpiration } \\
\mathrm{mol} \mathrm{H}_{2} \mathrm{O} \mathrm{m}^{-2} \mathrm{~s}^{-1}\end{array}$ & $\frac{\text { Leaf temperature }}{{ }^{\circ} \mathrm{C}}$ & $\begin{array}{l}\mathrm{CO}_{2} \\
\text { ratio }\end{array}$ \\
\hline Conventional & $21.33 \mathrm{a}$ & $0.20 \mathrm{a}$ & $4.67 \mathrm{a}$ & $32.17 \mathrm{~b}$ & $0.47 \mathrm{a}$ \\
\hline Irrigated & $18.14 \mathrm{~b}$ & $0.15 \mathrm{~b}$ & $3.88 \mathrm{a}$ & $32.83 \mathrm{a}$ & $0.42 \mathrm{a}$ \\
\hline CV (\%) & 11.17 & 18.77 & 18.28 & 1.53 & 16.51 \\
\hline
\end{tabular}

Columns with the same letter do not differ by the Tukey's test at $5 \%$.

Table 2. Physiological and biochemical variables in two phenological stages of mango tree (Palmer cultivar).

\begin{tabular}{|c|c|c|c|c|c|c|c|c|}
\hline \multirow{2}{*}{$\begin{array}{c}\text { Phenological } \\
\text { stage }\end{array}$} & $\begin{array}{c}\text { Photosynthesis } \\
\text { rate }\end{array}$ & Conductance & $\begin{array}{c}\text { Leaf } \\
\text { temperature }\end{array}$ & \multirow{2}{*}{$\begin{array}{l}\mathrm{CO}_{2} \\
\text { ratio }\end{array}$} & $\begin{array}{c}\text { Total } \\
\text { proteins }\end{array}$ & $\begin{array}{c}\text { Total soluble } \\
\text { sugars }\end{array}$ & $\begin{array}{l}\text { Reducing } \\
\text { sugars }\end{array}$ & $\begin{array}{c}\text { Non-reducing } \\
\text { sugars }\end{array}$ \\
\hline & $\mu \mathrm{mol} \mathrm{CO} \mathrm{Cm}^{-2} \mathrm{~s}^{-1}$ & $\mathrm{~mol} \mathrm{~m}^{-2} \mathrm{~s}^{-1}$ & ${ }^{\circ} \mathrm{C}$ & & \multicolumn{4}{|c|}{$\mathrm{mg} \mathrm{g}^{-1}$} \\
\hline Flowering & $21.56 \mathrm{a}$ & $0.16 \mathrm{~b}$ & $32.14 b$ & $0.36 \mathrm{~b}$ & $124.10 \mathrm{a}$ & $17.79 \mathrm{a}$ & $1.18 \mathrm{~b}$ & $16.45 \mathrm{a}$ \\
\hline Ripening & $18.86 \mathrm{~b}$ & $0.21 \mathrm{a}$ & $32.89 \mathrm{a}$ & $0.55 \mathrm{a}$ & $112.91 \mathrm{~b}$ & $11.87 \mathrm{~b}$ & $1.70 \mathrm{a}$ & $9.87 \mathrm{~b}$ \\
\hline CV (\%) & 11.41 & 24.92 & 1.46 & 15.55 & 11.05 & 10.56 & 18.19 & 11.84 \\
\hline
\end{tabular}


The lowest photosynthetic rate (Figure 2A) was observed when the highest dose (1.9 g of a.i. per linear meter of canopy) was applied with the mean value of $18.13 \mu \mathrm{mol} \mathrm{CO} \mathrm{C}^{-2} \mathrm{~s}^{-1}$, causing a $22 \%$ reduction. This reduction in the photosynthetic rate might be related to the decrease in stomatal conductance (Figure 2B), transpiration (Figure 2C) and leaf temperature (Figure 2D) resulting from the increase in the doses applied.

Stomatal conductance and transpiration showed a negative linear equation. Increased paclobutrazol doses caused a reduction of $30 \%$ in stomatal conductance and $28 \%$ in transpiration. The lowest stomatal conductance $\left(0.16 \mathrm{~mol} \mathrm{~m}^{-2} \mathrm{~s}^{-1}\right)$ and transpiration $\left(3.87 \mathrm{~mol} \mathrm{H}_{2} \mathrm{O} \mathrm{m}^{-2} \mathrm{~s}^{-1}\right)$ values were observed when the highest dose of the product was applied.

Lima Filho et al. (2002), evaluating the consequences of paclobutrazol application on gas exchange of mango trees, in the São Francisco River Valley, observed a significant decrease in photosynthetic rates, stomatal conductance and transpiration of 'Tommy Atkins' mangoes, as paclobutrazol doses increased, attributing these facts to the effect of paclobutrazol on the root system, since the concentrations applied caused the decrease of dry matter in the root system.

Increased doses caused stomatal closure (Figure 2B), and this adaptive mechanism in plants is used to prevent excessive water loss, mainly under stressful conditions. However, since this mechanism interferes with the photosynthetic activity (Figure 2A) by limiting the $\mathrm{CO}_{2}$ uptake by stomata, increasing leaf temperature (Figure 2D), it might decrease the photoassimilate production. According to Taiz \& Zeiger (2013), high leaf temperature might reach levels that are damaging to the plant metabolism and that cause decreased photosynthetic rates, reduced enzymatic activity, and even denaturation of enzymes.

The leaf tissue biochemical characteristics show that the total soluble sugar, protein and non-reducing sugar contents fit into the quadratic model (Figure 3). For total soluble sugar content (Figure 3A), the maximum value occurred with the dose of $1.09 \mathrm{~g}$ of a.i. per linear meter of canopy, which is equivalent to $15.90 \mathrm{mg} \mathrm{g}^{-1}$. Total leaf soluble protein contents obtained the maximum value of
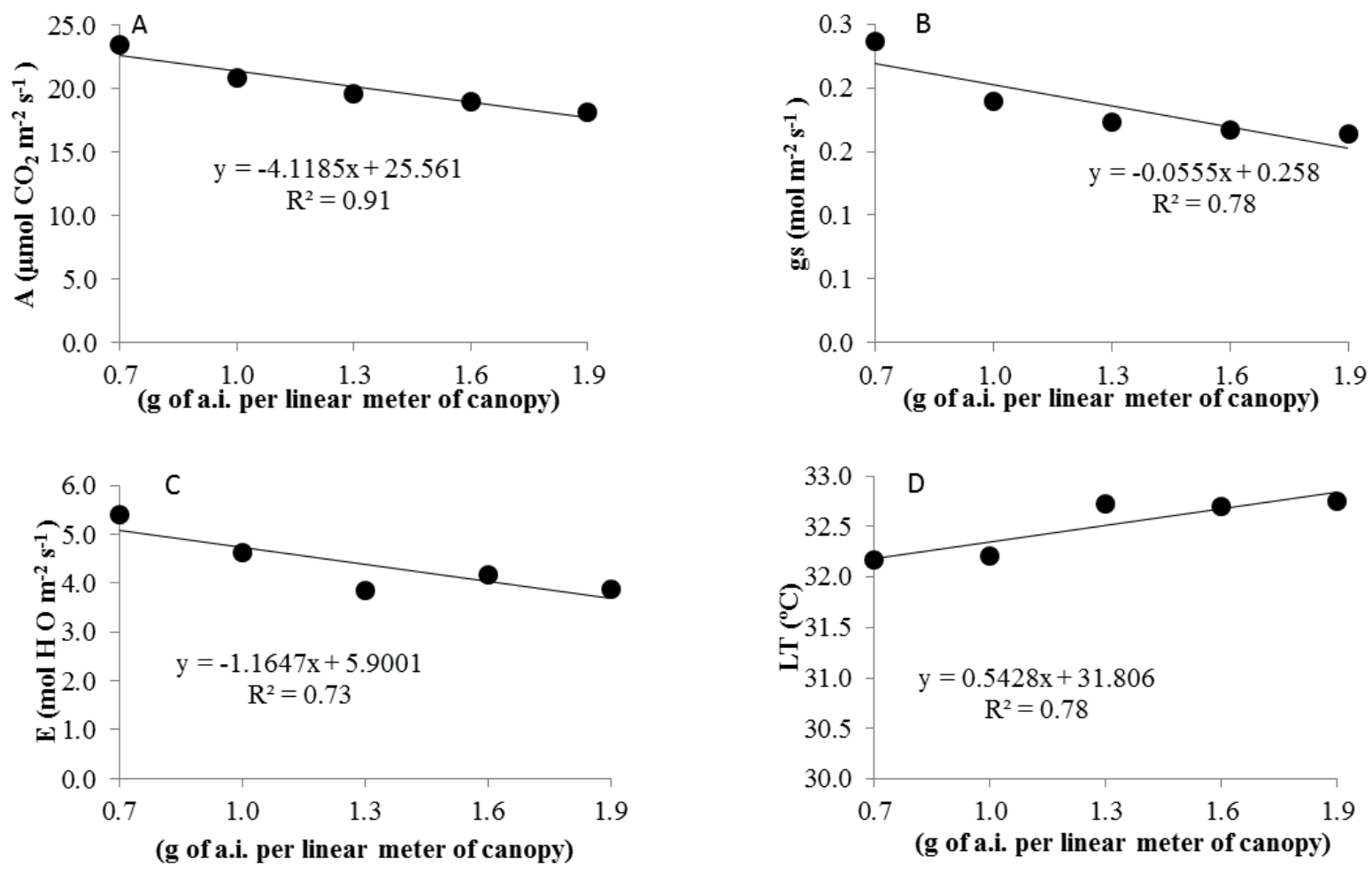

Figure 2. Photosynthesis rate (A), stomatal conductance (gs), transpiration (E) and leaf temperature (LT) of mango tree (Palmer cultivar), in terms of paclobutrazol application via irrigation in the eastern-western side of the plant. 
$127.86 \mathrm{mg} \mathrm{g}^{-1}$ (Figure 3C), which corresponds to a dose of $1.06 \mathrm{~g}$ of a.i. per linear meter of canopy. Regarding non-reducing sugars (Figure 3D), the highest content was $14.52 \mathrm{mg} \mathrm{g}^{-1}$, for the dose of $1.09 \mathrm{~g}$ of a.i. per linear meter of canopy.

The decrease in reducing sugar contents in leaves was linear (Figure 3B). The lowest reducing sugar content was observed with the application of $1.9 \mathrm{~g} \mathrm{~m}^{-1}$ of a.i. per linear meter of canopy, with a mean value of $1.31 \mathrm{mg} \mathrm{g}^{-1}$. These results corroborate those obtained by Cruz et al. (2007), who evaluated the carbohydrate contents in 'Tahiti' acid lime trees treated with paclobutrazol and found that they decreased as doses increased. According to Okuda et al. (1996), the magnitude of the decrease in reducing sugar contents of leaves depends on the concentration applied, decreasing as the product concentration increases.

According to Davenport (2007), carbohydrate contents in leaves are involved in panicle development and in the intensity of the flowering induction. Therefore, a decrease in total soluble sugar contents, reducing sugars, total proteins and estimates of sucrose content might have occurred due to the energetic demand for inflorescence formation. According to Bolding et al. (2003), the consumption of carbohydrates takes place when sprouting and flower emission occur. Paclobutrazol increased the percentage of flowering in plants and, consequently, the consumption of carbohydrates for the formation and development of panicles, resulting in lower carbohydrate contents in leaves.

Oliveira et al. (2013), evaluating the total soluble sugar contents in leaves over the tumescence period of floral gems, obtained a different behavior from the one found here: a quadratic reduction, in terms of different paclobutrazol doses. The lowest soluble sugar content was $33 \mathrm{mg} \mathrm{g}^{-1}$ of dry matter in leaves of 'Ubá' mango tree, which corresponds to the dose of $1.76 \mathrm{~g}$ of paclobutrazol per linear meter of canopy.

The decrease in the physiological and biochemical characteristics of leaf tissue, in terms of paclobutrazol doses, caused a decrease in the biochemical characteristics of the fruits (Figure 4). The increase in paclobutrazol doses caused a linear decrease of $31 \%$ in total soluble sugars, $54 \%$ in reducing sugars and $29 \%$ in non-reducing sugars.
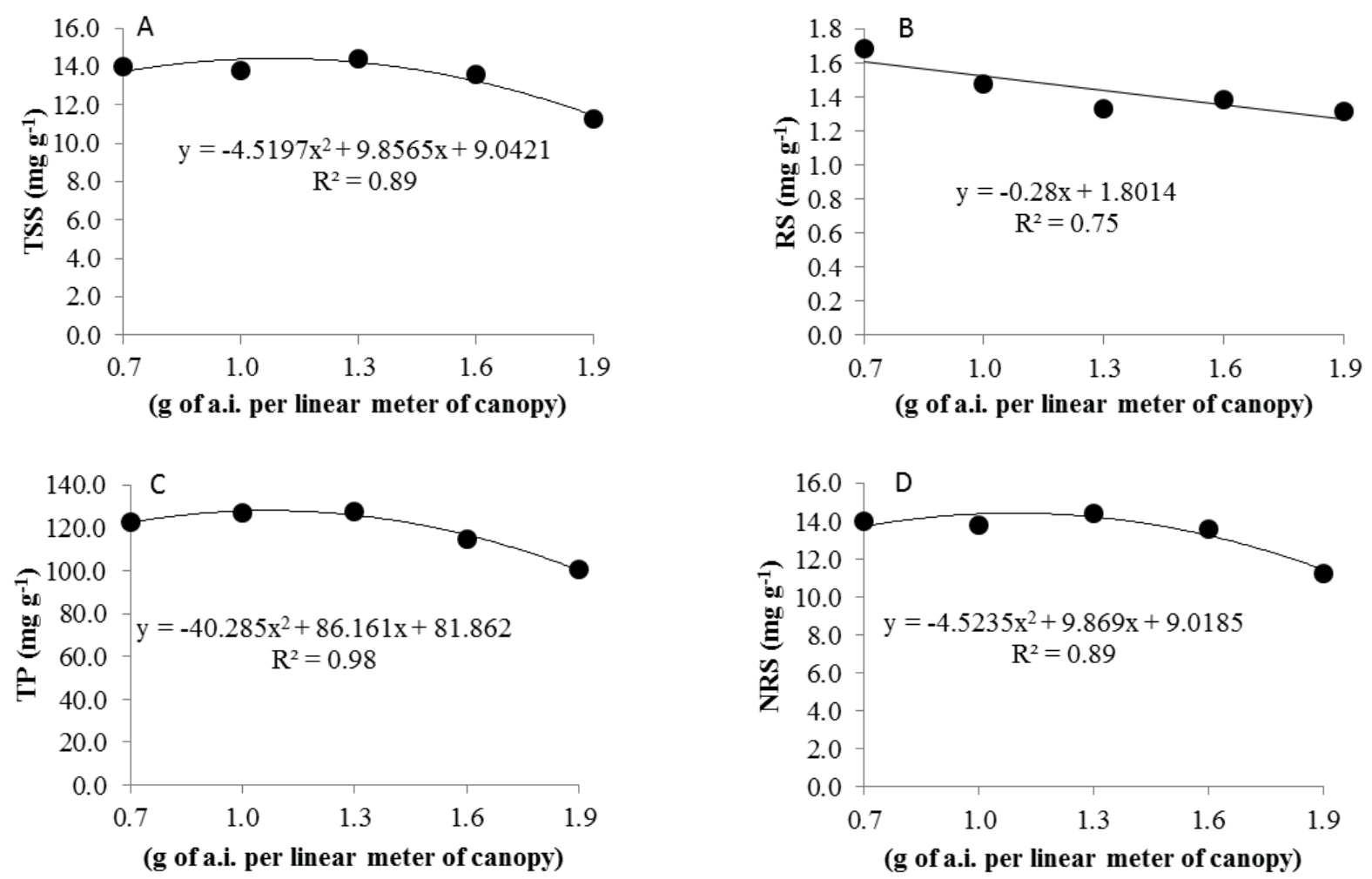

Figure 3. Total soluble sugars (TSS), total proteins (TP), reducing sugars (RS) and non-reducing sugars (NRS) in the leaf tissue of mango tree (Palmer cultivar), in terms of paclobutrazol doses applied via irrigation. 
This decrease might also be related to the fact that the highest doses of paclobutrazol increased the earliness of flowering. According to Salazar-Garcia \& Vasquez-Valdivia (1997), paclobutrazol applied to the soil allowed for earliness of flowering, and the higher the dose used in the soil, the earlier the flowering, fruiting and fruit ripening were reached. The low reducing sugar contents observed in higher doses
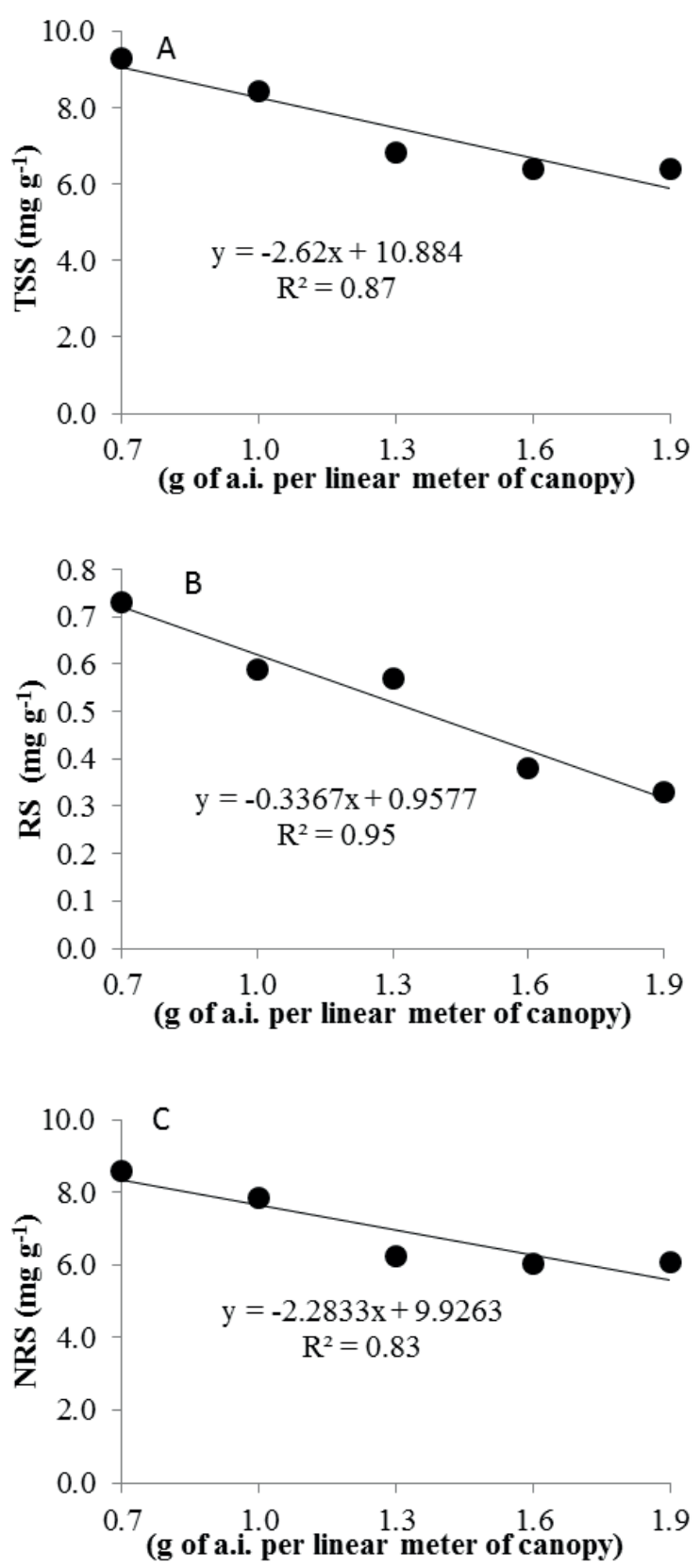

Figure 4. Total soluble sugars (TSS), reducing sugars (RS) and non-reducing sugars (NRS) in fruits of mango (Palmer cultivar), in terms of paclobutrazol application via irrigation.
(Figure 4B) are related to the fact that, when fruits ripe, glucose and fructose contents, the main representatives of this group of sugars, decrease as a result of consumption through respiration. Fruits with higher reducing sugar concentrations, observed in the lower doses (Figure 4), are preferred both for consumption as fresh fruit and for the industry, because of their sweeter taste (Chitarra \& Chitarra 2005).

No significant effects of application methods and doses via irrigation were observed on the nitrate reductase activity. This result is not in accordance with the ones found by Mendonça et al. (2001), who observed an interaction between paclobutrazol doses and the application of calcium nitrate, even without evaluating the nitrate enzyme activity, and this association between enzyme and applied paclobutrazol dose did not occur here. The nitrate reductase enzyme activity was higher in the root system $\left(0.28 \mathrm{NO}_{2}^{-} \mathrm{g}^{-1}\right.$ of fresh matter $\left.\mathrm{h}^{-1}\right)$ than in the leaf tissue $\left(0.13 \mathrm{NO}_{2}^{-} \mathrm{g}^{-1}\right.$ of fresh matter $\left.\mathrm{h}^{-1}\right)$.

This result differs from the ones found by Oliveira et al. (2011), in Campomanesia sp. plants, and Mesquita et al. (2015), with umbuzeiro (Brazil plum) plants, who observed that the nitrate reductase activity was much higher in leaves than in roots. According to Carelli \& Fahl (1991), roots are considered far less effective sites of assimilate consumption than the root, regarding nitrate assimilation.

It is worth noting that nitrate was applied to the leaves, and it was thus available to be absorbed and assimilated by the leaf tissue. Nitrate may be assimilated by the root system and produce amino acids, or it might be assimilated as $\mathrm{NO}_{3}$, translocated via xylem and reduced in the leaf tissue. According to Taiz \& Zeiger (2013), phloem nitrate transport is still controversial, and the nonexistence of active enzymes in the leaves might thus result from the inaccuracy of the evaluation methods adopted.

\section{CONCLUSIONS}

1. The paclobutrazol application via irrigation proved to be more efficient than the conventional application, allowing a greater assimilation of the product using a lower dose applied to the Palmer cultivar;

2. The application methods and doses applied via irrigation did not influence the nitrate reductase activity. 


\section{REFERENCES}

ALBUQUERQUE, J. A. S; MOUCO, M. A. do C. Manga: indução floral. Petrolina: Embrapa Semiárido, 2000.

ALMEIDA, E. I. B. et al. Ecofisiologia de mangueiras 'Tommy Atkins' submetidas a diferentes regimes hídricos e disponibilidade de luz.RevistaAgro@mbiente On-line, v. 9, n. 3, p. 251-260, 2015.

BOLDING, H. et al. Seasonal concentration of nonstructural carbohydrates of five Actinidia species in fruit, leaf and fine root tissue. Annals of Botany, v. 85, n. 4, p. 469-476, 2003.

BRADFORD, M. M. A rapid and sensitive method for the quantification of microgram quantities of protein utilizing the principle of protein-dye binding. Analytical Biochemistry, v. 72, n. 1-2, p. 248-258, 1976.

CARELLI, M. L. C.; FAHL, J. I. Distribuição da assimilação do nitrato e da matéria seca em plantas jovens de café cultivadas em diferentes níveis de nitrogênio. Bragantia, v. 50, n. 1, p. 29-37, 1991.

CASTRO NETO, M. T. Aspectos fisiológicos da mangueira sob condições irrigadas. In: EMPRESA BRASILEIRADE PESQUISA AGROPECUÁRIA. Informações técnicas sobre a cultura no semiárido brasileiro. Petrolina: Embrapa, 1995. p. 83-99.

CHITARRA, M. I. F.; CHITARRA, A. B. Pós-colheita de frutas e hortaliças: fisiologia e manuseio. 2. ed. Lavras: UFLa, 2005.

CRUZ, M. do C. M. da et al. Teores de carboidratos em limeiras ácidas 'Tahiti' tratadas com paclobutrazol. Revista Brasileira de Fruticultura, v. 29, n. 2, p. 222-227, 2007.

DAVENPORT, T. L. Reproductive physiology of mango. Brazilian Journal of Plant Physiology, v. 19, n. 4, p. 363376, 2007.

DAVIES, P. J. Plant hormones: biosynthesis, signal transduction, action. 3. ed. Dordrecht: Kluwer Academic Publishers, 2004.

FOOD AND AGRICULTURE ORGANIZATION (FAO). Mango world production. 2014. Available at: <http:// faostat.fao.org >. Access on: Feb. 15, 2016.

HUNTER, D. M.; PROCTOR, J. T. Paclobutrazol reduces photosynthetic carbon dioxide uptake in grapevines. Journal of the American Society for Horticultural Science, v. 119, n. 3, p. 486-491, 1994.

LIMA FILHO, J. M. P. et al. Ecofisiologia da mangueira. In: GENÚ, P. J. de C.; PINTO, A. C. de Q. (Orgs.). $A$ cultura da mangueira. Brasília, DF: Embrapa Informação Tecnológica, 2002. p. 39-49.

MENDONÇA, V. et al. Florescimento e frutificação de mangueira com uso de paclobutrazol, ethephon e nitrato de cálcio. Revista Brasileira de Fruticultura, v. 23, n. 2, p. 265-269, 2001.
MESQUITA, A. C. et al. Efeito da aplicação de fontes de nitrogênio em plantas de umbuzeiro propagadas via sexuada e assexuada. Revista Sodebras, v. 10, n. 1, p. 9-13, 2015.

MILLER, E. L. Use of dinitrosalicylic and reagent determination of sugar. Analytical Chemistry, v. 31, n. 3, p. 426-428, 1959.

MOUCO, M. A. C.; ONO, E. O. O.; RODRIGUES, J. D. Mango flower induction in the Brazilian Northeast Semi-arid with gibberellin synthesis inhibitors. Acta Horticulturae, n. 884, p. 591-596, 2010.

OKUDA, H.; KIHARA, T.; IWAGAKI, I. Effects of paclobutrazol application to soil at the beginning of maturation on sprouting, shoot growth, flowering and carbohydrate contents in roots and leaves of Satsuma mandarine. Journal of Horticultural Science, v. 71, n. 5, p. 785-789, 1996.

OLIVEIRA, G. P. et al. Caracterização de acessos de mangueira Ubá na zona da mata mineira. Ciência Rural, v. 43, n. 6, p. 962-969, 2013.

OLIVEIRA, L. J. de et al. Características agronômicas e atividade da redutase do nitrato em plantas de Campomanesia sp. sob estresse hídrico. Revista Agrarian, v. 4, n. 11, p. 43-53, 2011.

REIS, J. B. R. S. et al. Efeito de lâminas de irrigação e doses de PBZ na pós-colheita da mangueira cv. Haden no norte de Minas Gerais. Revista Brasileira de Agricultura Irrigada, v. 5, n. 3, p. 214-224, 2011.

SALAZAR-GARCIA, S.; VAZQUEZ-VALDIVIA, V. Physiological persistence of paclobutrazol on the 'Tommy Atkins' mango (Mangifera indica L.) under rainfed conditions. Journal of Horticultural Science, v. 72, n. 2, p. 339-345, 1997.

SALISBURY, F. B.; ROSS, C. W. Fisiologia vegetal. Veracruz: Iberoamérica, 1994.

SINGH, D. K. Triazole compounds in horticulture. New Delhi: Agrotech Publishing Academy, 2001.

TAIZ, L.; ZEIGER, E. Fisiologia vegetal. 4. ed. Porto Alegre: Artmed, 2013.

TONGUMPAI, P. Flower induction on mangoes. Kamphaengsem: s. d., 1999.

TRIBUZY, E. S. Variações da temperatura foliar e do dossel e o seu efeito na taxa assimilatória de $\mathrm{CO}_{2}$ na Amazônia Central. 2005. 84 f. Tese (Doutorado em Ecologia de Agroecossistemas) - Universidade de São Paulo, Piracicaba, 2005.

VU, J. C. V.; YELEONOSKY, G. Growth and photosynthesis of sweet orange plants treated with paclobutrazol. Journal of Plant Growth Regulators, v. 11, n. 1, p. 85-89, 1992.

YEMM, E. W.; WILLIS, A. J. The estimation of carbohydrates in plant extracts by anthrona. The Biochemical Journal, v. 57, n. 3, p. 508-514, 1954. 